\title{
Analysis of the Factors Affecting the Development of College Sports Associations in Western Liaoning
}

\author{
Qiangguo Lv \\ College of Physical Education \\ Bohai University \\ Jinzhou, Liaoning, China
}

\author{
Qiupeng Gao* \\ College of Education Science \\ Bohai University \\ Jinzhou, Liaoning, China
}

\begin{abstract}
College sports associations are an important part of China's sports associations, and also an essential driving force for colleges and universities to carry out sports work. With the advancement of Healthy China Initiative, the health awareness of college students has gradually strengthened. College sports associations are playing an increasingly crucial role in enriching students' campus cultural life, improving students' health and cultivating college students' lifelong sports awareness. Through the investigation and analysis of the factors affecting the development of college sports associations in western Liaoning, it is found that there are problems in its development in terms of management mechanism, number and function of instructors, activity content, and activity funds. In view of the problems in the students' sports associations, suggestions for promoting the development of sports associations are proposed for the development of sports associations.
\end{abstract}

Keywords-colleges and universities; sports associations; influencing factors

\section{INTRODUCTION}

With the continuous deepening of school physical education reform, the role played by student sports associations in college physical education has become prominent. The development of student sports associations is of great significance to the formation of quality education and lifelong sports awareness of college students. The student sports society not only plays an active role in mastering sports technology, cultivating sports interests, developing sports habits and enriching the campus sports culture, but also plays an irreplaceable role in relieving students' learning, life and mental stress.

\section{The BAsic Status Of COllege STUdents' SPORTS ASSOCIATIONS IN WESTERN LIAONING}

TABLE I. MAIN FACTORS AFFECTING THE DEVELOPMENT OF THE COMMUNITY $(\mathrm{N}=39)$

\begin{tabular}{|c|c|c|}
\hline Factor & $\begin{array}{c}\text { Select the number } \\
\text { of clubs }\end{array}$ & Percentage(\%) \\
\hline Lack of funding for activities & 21 & 53.85 \\
\hline Lack of professional guidance & 18 & 46.15 \\
\hline $\begin{array}{c}\text { The system of the person in charge } \\
\text { Of the association is not working } \\
\text { well }\end{array}$ & 9 & 23.07 \\
\hline Less activity, single event & 6 & 15.38 \\
\hline $\begin{array}{c}\text { The organization and management } \\
\text { Of the association is not good. }\end{array}$ & 15 & 38.46 \\
\hline
\end{tabular}

Phased Achievements of Humanities and Social Sciences Research of Liaoning Provincial Department of Education in 2019
It can be seen from Table I that $53.85 \%$ of the members of the society believe that the lack of funds for the activities affects the development of the association; $46.15 \%$ of the members of the sports associations believe that the association lacks professional guidance; and $38.46 \%$ of the members of the sports associations believe that the organization and management of the associations are not good; $23.07 \%$ of the associations believe that the operation of the responsible system of the association affects the development of the association; $15.38 \%$ of the associations indicate that the activities of the associations are less active, and the single content of the activities affects the development of the associations.

\section{A. Funding of student sports club}

It can be seen from Table I that the lack of funds for the main factors affecting the development of sports associations ranks first. Due to the small scale of activities carried out by sports associations, it is impossible to form a large social influence and it is generally difficult to obtain financial support from society and enterprises. The school itself does not have funds specifically for supporting the development of sports associations. The membership fees paid by members of the sports clubs are very limited. The funding problem is a major obstacle to the development of college sports associations.

TABLE II. SOURCE STATISTICS OF COMMUNITY ACTIVITIES (N=39)

\begin{tabular}{|c|c|c|}
\hline $\begin{array}{c}\text { Source of funding for club } \\
\text { activities }\end{array}$ & Quantity & $\begin{array}{c}\text { The } \\
\text { proportion(\%) }\end{array}$ \\
\hline Only dues & 26 & 66.67 \\
\hline $\begin{array}{c}\text { Funding for special activities of } \\
\text { the school }\end{array}$ & 0 & 0 \\
\hline Provided by sponsor & 6 & 15.38 \\
\hline Students share & 4 & 10.26 \\
\hline $\begin{array}{c}\text { Other (provided by the event } \\
\text { organizer) }\end{array}$ & 3 & 7.69 \\
\hline
\end{tabular}

From the statistics of the sources of social activities in Table II, it can be seen that the source of activities of the sports associations is relatively simple, and the activities of the associations mainly come from the membership fees paid by the members and the members of the participating activities. The main reason for the relatively simple source of funds is that the school does not have funds for special club activities. The student sports club activities need to apply for special funds from the higher authorities. However, due to the small influence of the organization activities or the relatively large funds required for the activities, the applications are often 
unable to It has been approved, and even the event holding day is approaching, and the activity funds have not been approved yet, thus delaying the development of the club activities.

\section{B. Lack of professional instructors in the development of sports associations}

TABLE III. SURVEY STATISTICS OF SPORTS CLUB INSTRUCTORS (N=39)

\begin{tabular}{|c|c|c|c|}
\hline \multicolumn{2}{|c|}{ Survey content } & $\begin{array}{l}\text { Select the } \\
\text { number of }\end{array}$ & Percentage \\
\hline \multirow{3}{*}{$\begin{array}{l}\text { Instructor } \\
\text { participation }\end{array}$} & Often participate & 8 & 20.51 \\
\hline & $\begin{array}{l}\text { Occasionally } \\
\text { participate }\end{array}$ & 3 & 7.69 \\
\hline & $\begin{array}{c}\text { Never } \\
\text { participate }\end{array}$ & 28 & 71.80 \\
\hline \multirow{3}{*}{$\begin{array}{l}\text { Guiding } \\
\text { experience }\end{array}$} & with rich & 6 & 15.38 \\
\hline & $\begin{array}{c}\text { General } \\
\text { experience }\end{array}$ & 12 & 30.77 \\
\hline & no experience & 21 & 53.85 \\
\hline \multirow{5}{*}{$\begin{array}{c}\text { How long is the } \\
\text { community } \\
\text { average? }\end{array}$} & Every month & 0 & 0 \\
\hline & $\begin{array}{l}\text { Contactt he } \\
\text { instructor once } \\
\text { Half term }\end{array}$ & 8 & 20.51 \\
\hline & one semester & 3 & 7.69 \\
\hline & $\begin{array}{l}\text { One academic } \\
\text { year or longer }\end{array}$ & 3 & 7.69 \\
\hline & Never contacted & 25 & 64.10 \\
\hline
\end{tabular}

It can be seen from Table III that only $20.51 \%$ of the instructors are often involved in organizing community activities and related guidance work. $71.80 \%$ of the instructors have never participated in the guidance work of the association, and $53.85 \%$ of the instructors have no experience in community activities, and $71.79 \%$ Instructors and the association's average contact time is one year or longer or even no contact. The instructor has no workload, no remuneration, and is responsible for the guidance of the sports associations, which affects the enthusiasm of the instructors. The participation and experience of the instructors of the student sports community is insufficient, and it is difficult to give full play to its guiding role, so that the society lacks effective professional guidance and systematic training.

\section{Management of sports club}

The traditional management method of student sports associations is the management of the school's competent departments, instructors and the associations themselves. The instructors' management of sports associations is mainly manifested in technical guidance and management supervision.
1) Establishment and implementation of the system of sports associations

TABLE IV. SURVEY STATISTICS OF SPORTS CLUB INSTRUCTORS (N=39)

\begin{tabular}{|c|c|c|c|}
\hline \multicolumn{2}{|c|}{ Project content } & $\begin{array}{c}\text { Number } \\
\text { of choices }\end{array}$ & $\begin{array}{c}\text { Percentage } \\
\text { (\%) }\end{array}$ \\
\hline \multirow{2}{*}{$\begin{array}{c}\text { Whether you have a } \\
\text { management system }\end{array}$} & Have & 39 & 100 \\
\cline { 2 - 4 } & No & 0 & 0 \\
\hline \multirow{2}{*}{$\begin{array}{c}\text { Implementation of } \\
\text { the } \\
\text { Management system }\end{array}$} & $\begin{array}{c}\text { General } \\
\text { implementation }\end{array}$ & 12 & 30.76 \\
\cline { 2 - 4 } & $\begin{array}{c}\text { The } \\
\text { implementation is } \\
\text { notgood }\end{array}$ & 21 & 53.86 \\
\hline
\end{tabular}

It can be seen from Table IV that the internal management of sports associations is relatively loose. Although sports associations have their own management systems, their management is not in place. $53.86 \%$ of the sports associations said that the implementation of the management system of the association is not good. Although the association has established rules and regulations, its implementation is not in place. Through interviews with the responsible persons of some associations, some associations were established only by the interests of individuals or minority people, lack of effective management, some of the work within the associations are not clear, and the management is chaotic. As the competent department of the school, there is no full-time management of sports organizations. Most of the personnel, with macro guidance, no detailed activity plans and long-term development plans, affect the healthy development of sports associations.

2) Change of the head of the sports club

TABLE V. SURVEY STATISTICS OF SPORTS CLUB INSTRUCTORS (N=39)

\begin{tabular}{|c|c|c|c|}
\hline \multicolumn{2}{|c|}{ Project } & $\begin{array}{c}\text { Number of } \\
\text { choices }(n=13)\end{array}$ & $\begin{array}{c}\text { Percentage } \\
\text { (\%) }\end{array}$ \\
\hline \multirow{2}{*}{$\begin{array}{l}\text { Association } \\
\text { leader } \\
\text { Appointment } \\
\text { system } \\
\end{array}$} & Have & 15 & 38.46 \\
\hline & No & 24 & 61.54 \\
\hline \multirow{3}{*}{$\begin{array}{c}\text { Form produced } \\
\text { by the } \\
\text { Head of the } \\
\text { association }\end{array}$} & $\begin{array}{c}\text { Association meeting } \\
\text { election }\end{array}$ & 9 & 23.08 \\
\hline & $\begin{array}{c}\text { Instructor } \\
\text { assignment }\end{array}$ & 6 & 15.38 \\
\hline & $\begin{array}{l}\text { Old person in } \\
\text { charge chooses to } \\
\text { train }\end{array}$ & 61.54 & 61.54 \\
\hline
\end{tabular}

The change of the sports clubs and the sustainability of the development are important links of the association. The main cadres of the sports associations play an important role in the development of the associations. It can be seen from Table $\mathrm{V}$ that $61.54 \%$ of the associations do not have a system of appointment of association heads. In the survey on the way in which the heads of associations were produced, $61.54 \%$ of the associations were selected and appointed by the previous heads, and only $23.08 \%$ of the heads of the associations were elected through the associations. Most sports associations do not pay attention to the connection and accumulation of information 
between new and old members. The sports association leaders only pay attention to the activities during their term of office, and do not pay attention to the training of the next person in charge. There is no suitable candidate for the change of time, leading to new and old. There is a lack of ideological communication and experience exchange between the responsible persons. The fine traditions and spiritual outlook cannot be passed down and carried forward, and the management and operation level of the associations is difficult to improve.

\section{3) Activities in sports club}

TABLE VI. STATISTICAL TABLE OF ACtivitiEs OF SPORTS ASSOCIATIONS $(\mathrm{N}=39)$

\begin{tabular}{|c|c|c|}
\hline Option & $\begin{array}{c}\text { Number of } \\
\text { choices }\end{array}$ & $\begin{array}{c}\text { Percentage of all } \\
\text { associations (\%) }\end{array}$ \\
\hline plan & 39 & 100 \\
\hline $\begin{array}{c}\text { Activity Feasibility } \\
\text { (SWOT) Analysis }\end{array}$ & 9 & 23.08 \\
\hline Capital budget & 33 & 84.62 \\
\hline $\begin{array}{c}\text { Preliminary } \\
\text { preparation } \\
\text { meeting }\end{array}$ & 15 & 38.46 \\
\hline Assess activity risk & 6 & 15.38 \\
\hline $\begin{array}{c}\text { Have an alternative } \\
\text { plan }\end{array}$ & 6 & 15.38 \\
\hline Early publicity & 15 & 38.46 \\
\hline Activity summary & 27 & 69.23 \\
\hline $\begin{array}{c}\text { Activity effect } \\
\text { display }\end{array}$ & 12 & 30.76 \\
\hline
\end{tabular}

It can be seen from Table VI that many associations have neglected the management of the whole process of community activities. The activities of many associations only stay on the planning, capital budget and activity summary. There is no feasibility analysis, activity evaluation and activities for the activities. The attention to the plan and the performance of the event show that many activities have been abandoned halfway, or the same problems have occurred many times, and the quality of the activities is getting worse.

\section{Activities in student sports club}

\section{1) Sports club members' evaluation of activities}

TABLE VII. STATISTICS ON THE EVALUATION OF CLUB ACTIVITIES BY MEMBERS $(\mathrm{N}=181)$

\begin{tabular}{|c|c|c|c|}
\hline \multicolumn{2}{|c|}{ Project name } & $\begin{array}{c}\text { Number } \\
\text { of people }\end{array}$ & $\begin{array}{c}\text { The } \\
\text { proportion(\%) }\end{array}$ \\
\hline \multirow{2}{*}{$\begin{array}{c}\text { Feeling after } \\
\text { participating } \\
\text { In the event }\end{array}$} & $\begin{array}{c}\text { Very satisfied, feel } \\
\text { happy }\end{array}$ & 21 & 11.60 \\
\cline { 2 - 4 } & $\begin{array}{c}\text { Feel the general } \\
\text { Not satisfied, very } \\
\text { tired after the event }\end{array}$ & 69 & 38.12 \\
\hline $\begin{array}{c}\text { Lead to the } \\
\text { withdrawal of } \\
\text { members }\end{array}$ & $\begin{array}{c}\text { Club activities are } \\
\text { nothing new }\end{array}$ & 84 & 50.28 \\
\hline \multirow{2}{*}{$\begin{array}{c}\text { Reason for the } \\
\text { community }\end{array}$} & $\begin{array}{c}\text { Community } \\
\text { guidance is not } \\
\text { professional or } \\
\text { wrong }\end{array}$ & 72 & 39.41 \\
\cline { 2 - 4 } & $\begin{array}{c}\text { Member's own } \\
\text { reasons }\end{array}$ & 25 & 13.81 \\
\hline
\end{tabular}

Table VII shows that only $11.60 \%$ of the members of the community participated in the event and expressed that they were very satisfied with the activities of the organization. After participating, they felt happy and happy. After the activities, $50.28 \%$ of the members thought that the activities did not achieve the expected results, but they were tired. The members of the sports clubs generally evaluate the activities of the clubs. From the statistics of the reasons that lead the club members to withdraw from the clubs, $46.41 \%$ of the members are not new because of the club activities, and $39.78 \%$ of the club members are unprofessional or wrongly withdrawing from the clubs. Only 13.81 members have withdrawn from the community for their own reasons.

\section{2) Sports club members' activities and targets}

TABLE VIII. COMMUNITY ACTIVITY CONTENT AND OBJECT STATISTICS TABLE $((\mathrm{N}=39))$

\begin{tabular}{|c|c|c|c|}
\hline \multicolumn{2}{|c|}{ Project } & $\begin{array}{c}\text { Number of people } \\
(n=13)\end{array}$ & $\begin{array}{c}\text { The } \\
\text { proportion(\%) }\end{array}$ \\
\hline \multirow{3}{*}{$\begin{array}{l}\text { Activity } \\
\text { content }\end{array}$} & Basic skills & 27 & 27 \\
\hline & $\begin{array}{c}\text { Foreign } \\
\text { exchange and } \\
\text { social practice }\end{array}$ & 12 & 12 \\
\hline & make friends & 0 & 0 \\
\hline \multirow{3}{*}{$\begin{array}{c}\text { The } \\
\text { main } \\
\text { object } \\
\text { of } \\
\text { activity }\end{array}$} & $\begin{array}{l}\text { Only for } \\
\text { members }\end{array}$ & 23 & 58.97 \\
\hline & $\begin{array}{c}\text { For all teachers } \\
\text { and students }\end{array}$ & 14 & 35.90 \\
\hline & other & 2 & 5.13 \\
\hline
\end{tabular}

It can be seen from Table VIII that the main activities of $69.23 \%$ of the associations are basic skills training, and the activities of $30.77 \%$ of the sports associations are external communication and social practice. The content of community activities is relatively simple. $58.97 \%$ of the activity targets are members of the community, and the instructor is the person in charge of the association. The limited ability of the responsible person limits the socialization process of the members of the association to a certain extent, affects the interest of the members of the community in the activities of the association, and also leads to the withdrawal of some members, which seriously affects the development of the sports association.

\section{PROBlems IN THE DEVElopment OF COLlEGE STUDENTS' SPORTS ASSOCIATIONS IN WESTERN LIAONING}

(1) Sports club activities have a single source of funds and scientific management of activities. The source of funding is mainly composed of membership fees. Although there are a small number of sponsorships, the lack of funds has reduced the scale or cancellation of club activities. Another reason is that the association is in the early stage of development and its scale is small. It is difficult to develop a large social influence and it is difficult to attract social and enterprise attention. Therefore, the probability of social sponsorship is low.

(2) The role and functions of the instructor are fully utilized, the instructor has no clear duties and obligations, the work is not affirmed, and the participation is not high. During the development of sports associations, some associations lack professional guidance, and some associations are in a state where unsupervised teachers or instructors are not sufficiently connected with the associations.

(3) In the process of the development of sports associations, their own management is relatively loose. Although the association has formulated some rules and regulations, its 
implementation is not good. The sustainable development of school sports associations has not formed a virtuous circle. Many associations do not have standardized club cadres to hire and compete for posts. The sports associations lack continuity and sustainability, resulting in low-level repetitive development of the associations and even stagnating.

(4) The content of sports club activities is relatively simple, mainly for students in school, and many are unattractive, which leads to the withdrawal of some members and seriously affects the development of sports clubs.

\section{SugGeStions ON THE DEVELOPMENT OF COLLEGE} STUDENTS' SPORTS ASSOCIATIONS IN WESTERN LIAONING

(1) To broaden the source of funding, the competent unit will take the lead in organizing the association to cooperate with the off-profit clubs, and further promote the competition between the college sports associations and various campus sports competitions.

(2) To strengthen the functions of the sports community instructors. The development of student sports associations should be fully integrated with professional teachers. Schools should clearly guide the duties of teachers and give corresponding treatment. The competent department of the school and the head of the student sports club strengthen communication and contact with the instructors and regularly report to the instructor about the recent activities and activities of the club, as well as problems in development.

(3) To improve the management system of student sports associations and strengthen the supervision of the competent departments. The activities of the sports associations and the development of the associations are often evaluated, and the assessment is publicized. The responsible persons are required to make regular rectifications so that the associations can identify their own deficiencies and make adjustments and improvements. The standardized association cadres hire and compete for the post-employment system, and the affiliated social associations regularly evaluate the performance and ability of the person in charge of the association.

(4) To strengthen the exchange of student sports associations between schools. Enrich the activities of the clubs, hold exchanges and competitions for inter-school student sports clubs, promote outstanding club leaders to learn and trainrelated clubs outside the school, and improve the organization and management capabilities of the club leaders.

\section{CONCLUSION}

College associations can enrich students' campus life, spread campus culture, and cultivate and develop students' interest in sports. By broadening the sources of funding, strengthening the functions of sports associations to guide teaching, improving the management system of student sports organizations, and strengthening the exchange of inter-school student sports organizations, we will build a distinctive campus community culture and promote the dissemination of sports culture in schools. Contemporary college students form a correct outlook on life and values and promote their healthy development.

\section{REFERENCES}

[1] Qingsong Zhu, Zheng Yang, and Jiezheng Zheng. Research on the Current Situation of Sports Associations in Hechi College and Its Development Countermeasures [J]. Hechi College, 2009, 6.

[2] Qin Haiquan, Jiang Liping, and Liang Tongfu. Study on the Management Model of Sports Associations in First-class Universities in the United States-Taking Duke University as a Typical Case[J]. Journal of Wuhan Institute of Physical Education, 2014, 05.

[3] BU Suli. Analysis of the Research Status of College Students' Sports Associations[J]. Sports Culture Guide, 2015, 01.

[4] Wang Zhe, and Liang Hongxia. The Status Quo and Influence Factors of College Students' Sports Associations in Hubei Province[J]. Journal of Nanjing Institute of Physical Education(Social Science Edition), 2014, 02. 